\title{
The earliest recordings of the works of Antonín Dvořák on standard gramophone records in the collection of the Antonín Dvorák Museum
}

\section{PetrKudláček}

Abstract: The article deals with a selection of standard gramophone records from the holdings of the National Museum - Antonín Dvořák Museum. The criteria for the selection were the age of the recordings, the material used for making the discs (shellac), and the recording method (mechanical). Analysis of the identification marks on the labels served for determination of the time (the recordings in question were made between 1903 and 1916) and place of their origin. Further research on historical perspectives and repertoire is adding to our knowledge about the lives of Czech opera singers (e.g. Bohumil Pták, Málka Bobková, Otakar Mařák, Emil Pollert et al.) and the issuing of recordings of classical music in this country, as well as about the tastes of the period and the popularity of specific compositions by Dvořák.

Key words: Antonín Dvořák, standard gramophone records, shellac discs, gramophone industry, Antonín Dvořák Museum, Rusalka, Gypsy Songs

This study gives a brief overview of a selected part of the music collection of the Antonín Dvoŕák Museum (MAD) with a focus on standard (shellac) gramophone records with recordings of the works of Antonín Dvořák. The second, main part of the study singles out the rarest of these recordings, which are owned by the MAD and are also among the very oldest recordings of the composer's works, and it analyses them from an historical perspective and with regard to their repertoire. This involves a total of ten separate gramophone discs with recordings made between 1903 and 1916. The selection is defined by the recording method used - the original mechanical recording of sound on gramophone records was typical until the first half of the 1920s, when it was gradually replaced by the more modern electronic recording method.

This work is financially supported by Ministry of Culture of the Czech Republic (DKRVO 2018/44, National Museum, 00023272). The author wishes to extend special thanks to Mr. Gabriel Gössel and to his colleagues at the Czech Museum of Music for their valuable advice and for providing materials. 
Among the oldest gramophone records generally, as in the case of this selection from the collection of the MAD, we find recordings of vocal works most frequently, and this was primarily dictated - as will be explained below - by the limitations of period recording techniques.

In this specific case, there are some arias from Dvořák's most famous opera Rusalka, op. 114 (1900), and two of the recordings are of a song from the cycle Gypsy Songs, op. 55 (1880).

\section{Status of the collection}

At present, the holdings of the Antonín Dvořák Museum collection of musical media encompass a total of 372 inventory numbers, among which there are standard and longplaying gramophone records with early and later recordings of the works of Antonín Dvořák. The historic shellac records are older, and their preservation is more threatened. These constitute $64^{1}$ of the inventory numbers (whether individual records or sets/albums of records).

The Antonín Dvořák Museum obtained the standard gramophone records in five instances as a gift, while another five were purchased from individuals or from second-hand bookshops. In one case, some non-collection materials were transferred to the collections of the MAD. The earliest acquisition was made in 1997, and the most recent took place in 2018.

The MAD collection contains items made by both Czech and foreign gramophone recording companies, many of which were established at the end of the nineteenth century and were active on the Czechoslovak market for gramophone records and playback equipment mainly during the first third of the twentieth century. The label found on the largest number of recordings is that of formerly the largest Czechoslovak gramophone recording company, Ultraphon (21 inventory numbers), and of its legal successor, Supraphon (11 inventory numbers), which still exists today. There are five items representing the company Esta (founded in 1930), which represented together with Ultraphon (in business as a purely Czech company since 1932) ${ }^{2}$ the only two Czech firms that were making and issuing recordings in former Czechoslovakia in the first half of the twentieth century. The two companies were merged in 1947, then on the basis of Beneš Decree No. 100/1945 dated 24 October 1945, they were transformed into a state-owned company, Gramofonové závody. ${ }^{3}$

In the MAD gramophone record collection, there are also recordings issued by foreign companies that were doing business on the Czechoslovak market in the first half of the twentieth century. Among them are nearly all of the world's gramophone companies that

1) The counts for the individual labels broken down in the text below do not seem to correspond to the total of 64. This is because inv. no. 5093 conceals various recordings issued by different recording companies.

2) For more about the history of this Czechoslovak brand, see GÖSSEL, Gabriel: Fonogram 2. Výlety k počátkům historie záznamu zvuku (Phonograph 2. Excursions into the Beginnings of the History of Audio Recording), Radioservis, Praha 2006, pp. 505-513 (hereinafter GÖSSEL 2006).

3) For more about nationalisation, see MÜLLER, Jan - PRAJZLER, Petr: Budování československého gramofonového průmyslu po druhé světové válce: 1945-1963 (Building up the Czechoslovak Gramophone Industry after the Second World War: 1945-1963), Acta phonographica, Ústí nad Labem 2017, pp. 10-13. 
had branches in Czechoslovakia at the time and were making and issuing records with Czech repertoire.

The largest number of records in the MAD collection were issued on the label His Master's Voice or on the Czech-language version Hlas jeho pána (9 inventory numbers), while the other recordings are on the labels Columbia / Columbia Phonograph Co. (6), Gramophone Concert Record / Concert Record "Gramophone" (4), Odeon / Odeon Record (4), Parlophon (4), Pathé (2), Telefunken (2), and Zonophone Record (1).

The alpha and omega for identifying any recording are the label on the gramophone record and the numerical or written information stamped into the material it is made of. The label "in its most abbreviated form contains only information about the publisher or its logo and the title of the recording. More detailed versions contain information about the performers and a number of other identifying marks." The most important piece of information for a relatively precise determination of when a recording was made is the matrix number. This number sometimes does not appear on the label, but it can always be found stamped in the gap between the paper label and the end of the recording (lead-out groove). Another important identifying mark that is always found on the label is the catalogue number, which connects the gramophone record or the recording on it to the recording company's catalogue of products. The two numbers may have different prefixes or suffixes (numerals, letters, or symbols preceding or following the main number), which provide other information, such as the diameter of the gramophone record, the price category, the name of the recording engineer etc. ${ }^{5}$

In most cases, the record catalogues of former gramophone recording companies have not been preserved. The dating of individual recordings based on matrix numbers and catalogue numbers therefore represents a time-consuming, laborious process, with researchers going through thousands of records literally by hand. Dating is gradually determined for individual recordings by using available promotional materials and other documentation from the individual companies and by making comparisons with available information on, among other things, the histories of the companies and the careers of the performers. ${ }^{6}$

For obtaining complete information about a selected gramophone recording, the aforementioned company catalogues are of the greatest assistance. These contain lists of recordings (names of compositions) ordered sequentially by their catalogue numbers, and they give the name of the composer of the work and of the performer. Some of the lists were compiled the other way around - alphabetically based on the names of the compositions/ composers/performers with the catalogue number added at the end of each entry. These

4) GÖSSEL, Gabriel - ŠÍR, Filip: Gramatika etiket gramofonových desek (The Grammar of Gramophone Record Labels), Národní muzeum (National Museum), Praha 2016, p. 11 (hereinafter GÖSSEL - ŠíR).

5) Ibid.

6) The study uses available lists of gramophone recordings of the relevant recording companies, which are the result of long-term research conducted by such important collectors as Gabriel Gössel (Czech Republic), Christian Zwarg (Germany), Richard K. Spottswood (USA), and many other people around the world who cooperate with each other. The lists provide approximate but sometimes very accurate dating. The work of Gabriel Gössel and Filip Šír is invaluable. Their publications offer a guide for dating Czech recordings. 
catalogues are helpful with the identification of recordings, and they let us get at least a basic idea about a given gramophone company's products during the period or about the repertoire being recorded by individual artists.

As usual with historical sources, however, the farther we go back into the past, the fewer preserved sales catalogues are to be found for the old recording companies. The situation is further complicated by several facts - the individual series of catalogue numbers were used out of order, ${ }^{7}$ the gramophone records were released around the world on the basis of supply and demand, taking into account the market for which the records were intended, and the situation is not made any simpler by the frequent changes of ownership in those days, which led to such practices as the reissuing of older recordings on new labels etc. ${ }^{8}$

\section{Standard gramophone records with early recordings of works by Antonín Dvořák}

In three cases, the Antonín Dvořák Museum obtained the gramophone records dealt with in this study as a gift from Mr. Josef Lipš, ${ }^{9}$ and another seven recordings were donated to the museum by Mr. Gabriel Gössel, a collector of older gramophone records and a populariser of historical recordings. ${ }^{10}$

Eight of the recordings are of arias from the opera Rusalka (one of the recordings is found twice in the collection - the second specimen is a reissue or "repressing"), and the other two gramophone records are recordings of Songs My Mother Taught Me from the cycle Gypsy Songs, op. 55.

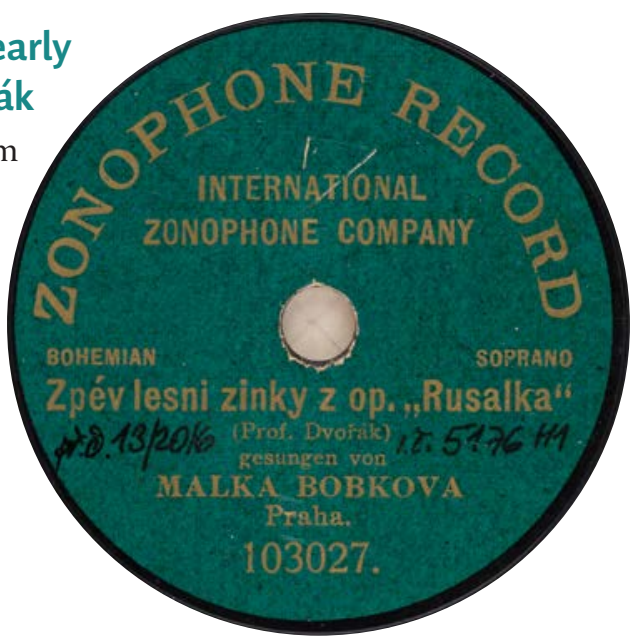

Gramophone record label of the brand Zonophone Record with the first recording of the aria of the wood sprite sung by Málka Bobková, 1903/

Etiketa gramofonové desky značky Zonophone Record s první nahrávkou árie lesní žínky v podání Málky Bobkové, 1903

NM-CMH-MAD $5176 \mathrm{Ml}$

7) I.e. not in chronological order and often with gaps caused by incomplete use of a given numerical series. 8) GÖSSEL, Gabriel - ŠÍR, Filip: Katalogy gramofonových firem ze začátku 20. století (Catalogues of Gramophone Recordings from the Early $20^{\text {th }}$ Century), pp. 3, 7. This study was published in the Proceedings of the Ninth Conference on Grey Literature and Repositories held at the National Technical Museum in Prague on 19 Oct. 2016. See http://repozitar.techlib.cz/record/1042/files/idr-1042_3.pdf [accessed 7 Mar. 2019].

9) This is a selection of records form a larger set that the Antonín Dvořák Museum obtained from the estate of Mr. Josef Lipš, who was the head of an unofficial club of collectors of standard gramophone records during the 1980s. NM-ČMH-MAD, acquisition no. 12/2005, inv. no. 8682-8684.

10) NM-ČMH-MAD, acquisition no. 13/2016, inv. no. 5176-5182. 


\section{Overview of the oldest recordings of works by Antonín Dvořák in the MAD collection ${ }^{11}$}

\begin{tabular}{|l|l|l|l|l|}
\hline Year & Title ${ }^{12}$ & Performer & Label & Inv. no. \\
\hline 1903 & $\begin{array}{l}\text { Zpěv lesní žínky } \\
\text { (Song of the Wood Sprite) }\end{array}$ & M. Bobková & Zonophone Record & 5176 \\
\hline 1906 & Zpěv lesní žínky & M. Bobková & Odeon Records & 5179 \\
\hline $1908-1909^{13}$ & Zpěv lesní žínky & M. Bobková & Odeon Records & 5181 \\
\hline 1905 & $\begin{array}{l}\text { Cigánská píseň } \\
\text { (Gypsy Song) }\end{array}$ & O. Mařák & Columbia Phonograph & 8684 \\
\hline 1907 & $\begin{array}{l}\text { Když mě stará matka } \\
\text { (Songs My Mother Taught } \\
\text { Me) }\end{array}$ & O. Mařák & Gramophone Concert Record & 8682 \\
\hline 1907 & $\begin{array}{l}\text { Zpěv prince } \\
\text { (Song of the Prince) }\end{array}$ & O. Mařák & Gramophone Concert Record & 8683 \\
\hline $1906-1908^{14}$ & $\begin{array}{l}\text { Árie prince } \\
\text { (Aria of the Prince) }\end{array}$ & B. Pták & Pathé Records & 5178 \\
\hline $1906-1908$ & $\begin{array}{l}\text { Árie vodníka } \\
\text { (Aria of the Water Goblin) }\end{array}$ & V. Kliment & Pathé Records & 5177 \\
\hline 1908 & Árie vodníka & E. Pollert & Gramophone Concert Record & 5180 \\
\hline 1916 & $\begin{array}{l}\text { Měsícku na nebi hlubokém } \\
\text { (Song to the Moon) }\end{array}$ & E. Žárská & Columbia & 5182 \\
\hline
\end{tabular}

These titles are some of the oldest Czech gramophone recordings. Emile Berliner, the American inventor of this medium and of the gramophone apparatus for audio recording and playback, patented his invention in 1887. In 1894 he founded the world's first recording company, the United States Gramophone Company, and he began issuing his records commercially. The first Czech recordings saw the light of day back during the first years of the twentieth century. Mostly this involved arias from Bedriich Smetana's operas, folk songs, patriotic songs, and Kde domov můj (Where Is My Home?), later the national anthem of Czechoslovakia. The performer was the Czech opera singer František Pácal ${ }^{15}$ who was engaged at the Vienna Court Opera from 1895 to 1905. Initially the recordings were made in Vienna or Berlin, but from 1902, recordings began to be made in Prague as well. ${ }^{16}$

The first performers of the works of Antonín Dvořák on the oldest gramophone records were opera singers who were performing the same roles on the stage of the National Theatre in Prague. Some of these names appear on the list of recordings from the MAD collection shown above. Among them we find, for example, Růžena Maturová, Václav Kliment, Otakar

11) This list is in chronological order. To make it as clear as possible, the ordering of the individual recordings also takes into account the name of the performer and/or the title of the recorded composition.

12) The Czech titles are left as they appear on the labels of the gramophone records.

13) This is a repressing (reissue) of the recording from 1906.

14) The dating of recordings is very sporadic and difficult in the case of the Pathé label.

15) On early gramophone labels, his name is given as Franz Pacal.

16) GÖSSEL, Gabriel: Gramophone Company Czech Catalogue 1900-1915.doc - this electronic source is the private property of Mr. Gössel [accessed 9 Mar. 2019] (hereinafter GÖSSEL: Catalogue). 
Mařák, Málka Bobková, Emil Pollert, Marie Klánová, Anna Slavíková, Bohumil Pták, and František Pácal (who is mentioned above). Besides arias from operas by Czech and foreign composers, they also performed patriotic songs and arrangements of folk songs. From among the works of Antonín Dvořák, this mostly involved arias from the opera Rusalka and some of the composer's songs.

The oldest gramophone recording in the MAD collection ${ }^{17}$ dates from 1903. On side one is the aria of the wood sprite Mám zlaté vlásky, mám (I Have Golden Hair, I Do) from Act III of the opera Rusalka sung by Málka Bobková with piano accompaniment. ${ }^{18}$ On the other side of the record is the Czech folk song Ach, není tu, není (There's Nothing to Please Me, also with piano accompaniment) sung by a certain Josefina Krausová. The recording was made in early 1902 in Berlin. Antonín Dvořák set the text of this song to music in $1886^{19}$ using certain elements of original folk melodies, but the recording in question uses the folk song in its original form.

Back then, technological limitations allowed the recording of only a limited repertoire, and the duration could not exceed a few minutes. The mechanical recording technique that was characteristic of the first stage of development of audio recording was especially limited by the low sensitivity of the membrane, which was only capable of capturing sounds with medium frequencies. In addition, when actually making the recording, the performer had to get as close as possible to the recording horn. For this reason, it was only possible to record the human voice or a solo violin satisfactorily. For reasons of capacity, these old gramophone discs could only be used to record short compositions, which were also cut or arranged in various ways (and this is also the case with some of the recordings in the MAD collection). ${ }^{20}$ The aria of the wood sprite has a total duration of one minute and forty seconds. Side two lasts a full two minutes.

The recording was issued on one of the world's earliest gramophone labels, Zonophone Record. The brand originally belonged to the American recording firm The International Zonophone Company, founded in 1899 by Frank Seaman in New Jersey. Because of the initial successes the firm enjoyed for its recordings of the world's great opera singers (including Enrico Caruso), the company soon represented unwanted competition for the largest recording companies of the day - one of them, the English firm The Gramophone Company Ltd., bought out the brand at the end of 1903 and began to use it as its secondary,

17) NM-ČMH-MAD, inv. no. 5176.

18) This is also the very oldest recording of this aria. Cf. ŠÍR, Filip - GÖSSEL, Gabriel: Unikátní nahrávky árií z Dvořákovy Rusalky na šelakových gramodeskách z počátku 20. století (Unique Recordings of Arias from Dvořák's Rusalka on Shellac Gramophone Discs from the Early 20 $0^{\text {th }}$ Century). See http://muzeum3000. nm.cz/clanek/unikatni-nahravky-arii-z-dvorakovy-rusalky-na-selakovych-gramodeskach-z-pocatku-20stoleti [accessed 9 Mar. 2019]. The date mentioned in the article (1902) refers to the oldest recording of any aria from Rusalka (aria of the Prince sung by Stanislav Orzelský). The song of the wood sprite was actually recorded in 1903 in Prague. See GÖSSEL: Catalogue, electronic source cited in footnote no. 16.

19) He published it together with three other musical settings of texts of Slovak songs as part of the cycle $\checkmark$ národním tónu (In Folk Tone), op. 73.

20) Cf. LOCHMAN, Adolf: Gramofonová deska (The Gramophone Disc), Práce (Labour), Praha 1955, pp. 36-37. 
cheaper label reserved for artistically less demanding repertoire, mainly folk music, with the exception of a very few recordings of concert ensembles and opera singers (Emil Pollert, Otakar Mařák, Bohumil Benoni, Václav Kliment, Mirko Štork). The recordings intended for the countries of former Austria-Hungary were issued on records with diameters of 7 and 10 inches. They had a dark green label with the inscription "Zonophone Record" and were released with catalogue numbers in the 100,000 series. ${ }^{21}$ The recording of the aria of the wood sprite is assigned the catalogue number 103027, while side two has the number 103028. The diameter of the disk is just under $18 \mathrm{~cm}$, i.e. ca. 7 inches.

Málka (Amálie) Bobková (1874-1956) was one of the most important opera singers of the early twentieth century. In 1901 she earned a permanent engagement at the National Theatre in Prague after having made several guest appearances there. For ten years, she remained at the National Theatre, where she had success performing young female characters in operas by Czech and foreign composers (Bedřich Smetana, Antonín Dvořák, and Wolfgang Amadeus Mozart among others). The role from Dvořák's operas that Málka Bobková sang most frequently on the stage of the National Theatre during her career was that of the wood sprite (sometimes also appearing in the role of the Kitchen Boy). ${ }^{22}$ She also sang the role at the premiere of Rusalka on 31 March 1901 at the National Theatre in Prague. In this and other works by Dvořák (Šelma sedlák - The Cunning Peasant, Armida, Requiem, Dimitrij, Jakobin), she appeared alongside many great vocal colleagues, and with them she made her first recordings, alone or in duets (with Anna Slavíková, Marie Klánová, Otakar Mařák, František Pácal, Bohumil Pták, Václav Kliment, Emil Pollert, and Bohumil Benoni), as the popularity of gramophone records rose sharply. In particular, she and Otakar Mařák made a seasoned pairing. The operas of Bedřich Smetana were the linchpin of Málka Bobkovás repertoire at the National Theatre. ${ }^{23}$ Again in the case of recordings made for E. Berliner's recording firm The Gramophone Company, Smetana's works are most frequently encountered (she had the greatest number of productions to her credit in the role Vendulka from the opera Hubička - The Kiss). Málka Bobková made 27 recordings for this company from 1902 to 1908, and she made the largest number of those recordings in 1905 (six). ${ }^{24}$

Like other performers, in time Málka Bobková began recording the arias she was singing on the theatrical stage for multiple gramophone companies. The Odeon label was another wellknown brand for which many Czech artists recorded. It was founded in 1903 by the Berlin firm International Talking Machine, which introduced gramophone records with recordings on both sides to the market the very next year. Because it was standard practice at the time to record on only one side, two-sided records brought the firm great success, so Odeon

21) GÖSSEL 2006, op. cit. in footnote no. 2, pp. 530-533.

22) Cf. Národní divadlo. Soupis repertoáru od roku 1883 (National Theatre. List of Repertoire from 1883). See http://archiv.narodni-divadlo.cz [accessed 9 Mar. 2019].

23) ŠTĚDROŇ, Bohumír: Bobková, Amálie [entry], in: Československý hudební slovník osob a institucí. A-L (Czechoslovak Musical Dictionary of Persons and Institutions. A-L), Státní hudební vydavatelství (State Music Publishing), Praha 1963, p. 112. Cf. Soupis repertoáru od roku 1883 (List of Repertoire from 1883), op. cit. in footnote no. 22.

24) GÖSSEL: Catalogue, electronic source cited in footnote no. 16. 
expanded quickly to the rest of Europe and the USA. ${ }^{25}$ Like in the case of E. Berliner's firm, Odeon also initially made its Czech recordings in Berlin or Vienna, but production was soon moved to Prague. Once again, František Pácal was a pioneer in making recordings, and he joined Vilém Heš in making two dozen records. The first opera recordings made for Odeon in Prague date from 1906/1907, and other famous names appear on them, including some performers who are heard on the records in the MAD collection: Otakar Maŕák, Málka Bobková, Bohumil Pták, Václav Kliment, Emil Burian, Anna Slavíková etc. Otakar Mařák was one of the most prolific (as he was on the other labels for which he recorded), making more than thirty recordings, while Emil Burian exceeded that number by nearly double. ${ }^{26}$

The repertoire recorded for the Odeon label did not differ fundamentally from the competition - compositions by Bedřich Smetana, folk songs, and patriotic songs predominate. The most frequently encountered works of Antonín Dvořák are again arias from Rusalka, the composer's songs, and some of the Slavonic Dances.

Between 1906 and 1908, Málka Bobková made 17 gramophone recordings for the Odeon label (11 of them were solo recordings), and the music of Bedrich Smetana is the most plentifully represented. ${ }^{27}$ Probably the only recording of Antonín Dvořák's music that the artist made for this label is side one of the gramophone record in the MAD collection, ${ }^{28}$ published in 1906. Again, it is the aria of the wood sprite accompanied by piano (the duration of the recording is 2' 11"); on side two is the Romance from the opera Mignon by the French opera composer Ambrois Thomas (duration 3' 26"). That recording ${ }^{29}$ is found in the collection in the form of a repressing (i.e. reissue) dated ca. 1908/1909. ${ }^{30}$

The second oldest gramophone recording of the music of Antonín Dvořák in the MAD collection is Cigánská písen̆ (Gypsy Song), sung in 1905 with piano accompaniment by Otakar Mařák, who is mentioned several times above. ${ }^{31}$ The title on the Columbia Phonograph Co. label refers to the fourth song from the cycle of seven Gypsy Songs, op. 55, Když mě stará matka (Songs My Mother Taught Me). The disc is recorded on one side only, and it has a duration of 2' 59 "'32

The beginnings of the Columbia Phonograph Co. go back to the turn of the 1880s and '90s in the USA. The company originally sold phonograph cylinders, but it expanded its assortment of goods and began releasing its own gramophone records in 1901. Within

25) GÖSSEL, op. cit. in footnote no. 2, p. 452.

26) GÖSSEL, Gabriel: LINDSTRÖM_A_DISKO.xls - the electronic source is the private property of Mr. Gössel [accessed 10 Mar. 2019].

27) Op. cit. in footnote no. 26 [accessed 10 Mar. 2019].

28) NM-ČMH-MAD, inv. no. 5179.

29) NM-ČMH-MAD, inv. no. 5181.

30) ZWARG, Christian: Odeon.xls - electronic source, see https://www.truesoundtransfers.de/disco.htm [accessed 10 Mar. 2019].

31) He is identified on the labels of the first gramophone records as Otokar Mařák.

32) NM-ČMH-MAD, inv. no. 8684. 
a year, it already had a regional office for the Czech lands. ${ }^{33}$ Like its competitors, Columbia also focused on satisfying the taste of its listeners, concentrating on releasing popular music, comedy, and popular arias from operas by Czech and foreign composers. Again we encounter folk songs, patriotic songs, and arias performed by leading opera singers such as Otakar Mařák (nearly forty recordings), Václav Kliment, Emil Pollert, František Šír etc., and in later years Bohumil Pták and Erma Žárská appear as well, but according to available data, ${ }^{34}$ the repertoire of this label for the Czech lands was not as extensive as that of the two previously mentioned companies. Smetana's operas and Vilém Blodek's opera V studni (In the Well) are most numerously represented. Dvořák's music is represented by a single recording - the aforementioned disc owned by the MAD.

Otakar Mařák also recorded the same song as for Columbia two years later, this time under the actual title Když mě stará matka (Songs My Mother Taught Me) on a two-sided gramophone record for the Gramophone Concert Record label of The Gramophone Company. Again it is for voice and piano, and the duration is two minutes and fifty seconds. Side two has the song Ó, jak jsi krásná (O How Beautiful You Are) by Emanuel Chvála (2' 42”), also sung by Otakar Mařák. ${ }^{35}$

This opera singer, whose period of greatest fame at Prague's National Theatre falls between the years 1903 and 1907, became the most popular and most frequently cast member of the opera ensemble at that theatre because of his perfect mastery of the Czech and worldwide repertoire. He was a leading interpreter of

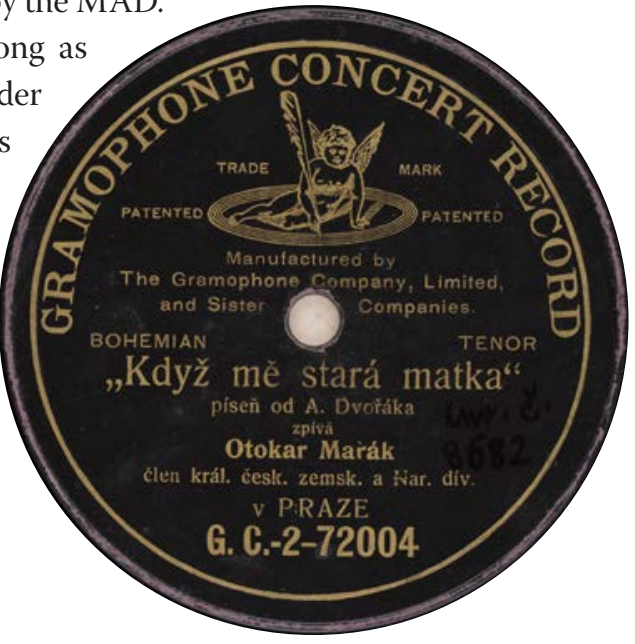

Gramophone record label of the brand Gramophone Concert Record with a recording of the song Songs My Mother Taught Me sung by Otakar Mařák, 1907 /

Etiketa gramofonové desky značky Gramophone Concert Record s nahrávkou písně Když mè stará matka v podání Otakara Mařáka, 1907 NM-ČMH-MAD $8682 \mathrm{Ml}$

all of Smetana's operas, and he was also outstanding in the works of Antonín Dvořák and other Czech classics. ${ }^{36}$ As a versatile singer with both an operatic and a concert repertoire,

33) GÖSSEL 2006, op. cit. in footnote no. 2, pp. 367-368.

34) GÖSSEL, Gabriel: COLUMBIA_cz_stará.doc - the electronic source is the private property of Mr. Gössel [accessed 12 Mar. 2019]; SPOTTSWOOD, Richard: The Columbia Series, 2016 - electronic source, see https://78records.files.wordpress.com/2016/08/columbia-e_spottswood.pdf [accessed 16 Mar. 2019] (hereinafter SPOTTSWOOD).

35) NM-ČMH-MAD, inv. no. 8682.

36) ŠTĚDROŇ, Bohumír: Mařák, Otakar [entry], in: Československý hudební slovník osob a institucí. M-Ž (Czechoslovak Musical Dictionary of Persons and Institutions. M-Ž), Státní hudební vydavatelství (State Music Publishing), Praha 1965, pp. 56-57. 
he was highly engaged in the developing gramophone industry, as is shown by numerous recordings on several of the lists of gramophone companies' records used in this study.

Near the end of 1907, Otakar Mařák, made ten recordings for The Gramophone Company at a single recording session. Besides the aforementioned song Když mé stará matka (Songs My Mother Taught Me), the MAD collection also contains a disc with a recording of the Prince's aria from Rusalka, Vidino divná, presladká (Wondrous Vision, Immensely Sweet), with the generic title Zpèv prince (Song of the Prince) on the label. The voice is accompanied by an unidentified orchestra. The duration is two minutes and forty-five seconds. On side two is Árie Jarka (Jarek's Aria) from Smetana's opera Čertova stèna (The Devil's Wall, duration: 2' 57").37

Another pair of gramophone records was issued by the French company Pathé between 1906 and 1908. The first of these records ${ }^{38}$ again has the more generic title Arie prince (Aria of the Prince) on the label, but this time it conceals the aria Vim, že jsi kouzlo (I Know You Are Magic) sung by Bohumil Pták. This recording of his voice accompanied by an unidentified orchestra lasts two minutes and twenty-nine seconds. On side two of the record is the same opera singer performing Árie Ctirada (Ctirad's Aria) from the opera Šárka by Zdeněk Fibich (2'34").

The second disc $^{39}$ is a recording of the aria Celý svèt nedá ti, nedá (The Whole World Will Not Give You). The title on the label is Arie vodnika (Aria of the Water Goblin, duration: 2' 36"). On side two is Árie Beneše (Benešs Aria) from the opera Dalibor (2'35"). On both sides of the record, the performer of the vocal part is Václav Kliment.

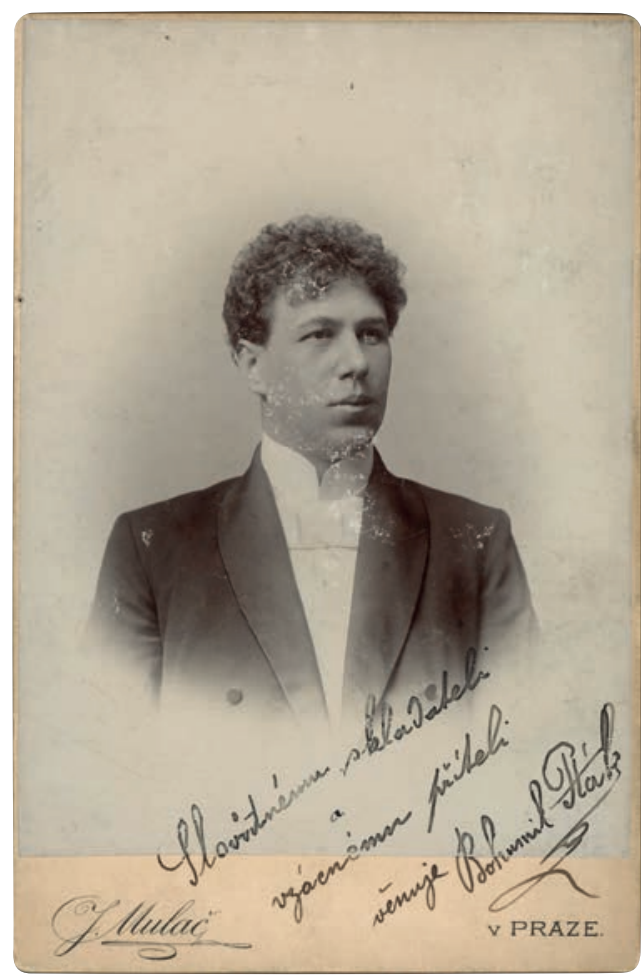

\section{Bohumil Pták (1869-1933)}

Photograph, J. Mulač, Prague, ca. 1900 / Fotografie, J. Mulač, Praha, kol. 1900

NM-HM, Department of Theatre / Divadelní oddělení H6D-27F31

The gramophone company Pathé,

the label of which exists in France to this day, was founded in 1895 in Paris. It originally manufactured cylinders for phonographic recordings, but it soon began making the recordings themselves, and later it added the manufacture of its own phonographs. The

37) NM-ČMH-MAD, inv. no. 8683.

38) NM-ČMH-MAD, inv. no. 5178.

39) NM-ČMH-MAD, inv. no. 5177. 


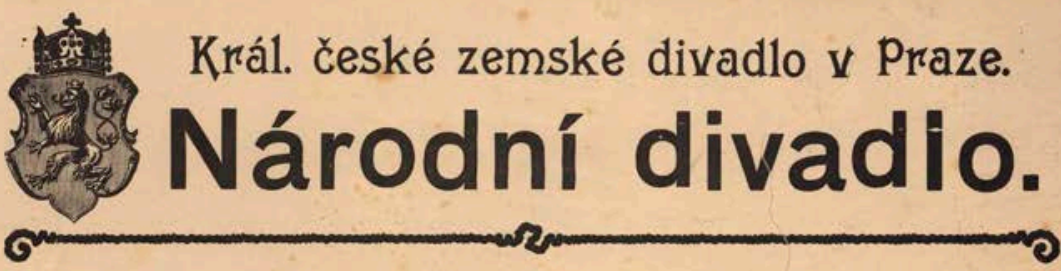

V nedèli dne 31. brezzna 1901.

Nimo prèoplaceni.

\section{Poprué:}
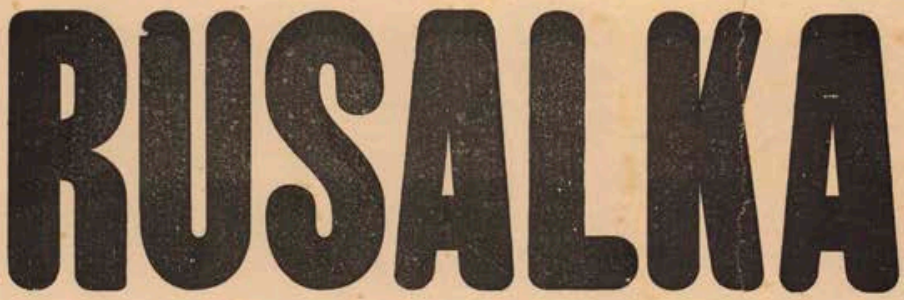

Lyrická pohádka o třech dẹjstvieh od Jaroslava Kvapila.

Hudbu složil Antonin Dvorák.

Dirigent: Karel Kovarovic. Regisseur: Robert Polak.

\section{OSOBY:}

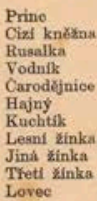

Karel Burian.

Marie Kubatova.

Rubena Maturova.
Vuclay Kliment.

Václav Kliment.
Rữena Bradaćcovă.

Adolf Krossing.

Vilemina Hajková.

Amalie Bobkova

Helena $\mathrm{z}$ Towarnických.

Frantisek Sir.

Družins princova, hoste, lesnt żinky, rusalky.

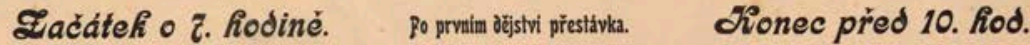

VP pondéli dne 1. du6na 1901.

176. hira (\$. dtortfia) v prodplacant.

\section{Prodaná nevěsta.}

Poster announcing the premiere of Rusalka at the National Theatre on 31 March 1901 It lists the performers, most of whom later recorded their parts on gramophone records. I Plakát ohlašující premiéru Rusalky v Národním divadle dne 31. března 1901

Uveden seznam interpretů, z nichž většina poté natáčela své party na gramofonové desky. NM-HM, Department of Theatre / Divadelní oddělení H6C-113 
company was highly successful, as can be seen from the fact that it did not introduce the regular production of gramophone discs until 1906, by which time it was clear which audio medium would take over the future gramophone market. The products of the company Pathé were characterised by a number of special technical characteristics. The discs of this brand had unusual parameters, such as a rotational speed of 90-100 rpm (as opposed to the standard speed of $78 \mathrm{rpm}$ ). The sound was recorded on the groove from inside out, and it was made using a vertical-cut groove, which had been the method typical of the wax cylinders, instead of the lateral-cut groove used for gramophone records. These discs also had unusual diameters. Initially they were recorded only on one side, and they lacked the traditional paper label. A special gramophone was required to play these records. ${ }^{40}$

The Pathé gramophone records in the MAD collection are characterised by the absence of a paper label - information about the recording is engraved directly into the material the record is made of and is highlighted with white filler. The diameter of $29 \mathrm{~cm}$ (11.5") is another of the atypical parameters mentioned above. Czech repertoire began to appear on Pathé gramophone discs in 1906, and about 850 recordings were made for the company. The dating of the first discs without paper labels fits in the period between 1906 and 1908. ${ }^{41}$ Among the opera singers who made these recordings were Marie Kubátová, Olga Valoušková, Václav Kliment, Bohumil Pták, and František Šír. Stanislav Orzelski also recorded an aria from the opera Rusalka for Pathé (Píseň prince - Song of the Prince).

Bohumil Pták (1869-1933), an opera singer with a rather broad repertoire, was engaged at the National Theatre in Prague from 1896 to 1911, and he was highly regarded as a performer of heroic and lyrical characters, especially in the Smetana repertoire. ${ }^{42}$ He was the first to perform a number of roles in Czech operas, including the Prince in Dvořák's Rusalka, in which he was a last-minute stand-in for Karel Burian, whose name was still listed on the theatrical poster for the premiere.

Václav Kliment (1863-1918), one of the top singers on the leading Czech stage (he was engaged in 1893 and remained there until the end of his life), also took part in the premieres of a number of new Czech operas. At the premiere of Rusalka, he sang the part of the Water Goblin. $^{43}$

The next gramophone recording from the MAD collection also involves the premiere of Dvořák's most famous opera. Emil Pollert (1877-1935), one of the most prominent and successful performers of comic bass roles, was especially outstanding as Kecal in Smetana's opera Prodaná nevěsta (The Bartered Bride) or as the Water Goblin in

40) GÖSSEL 2006, op. cit. in footnote no. 2, pp. 480-481.

41) GÖSSEL - ŠÍR, op. cit. in footnote no. 4, p. 59.

42) ČERNUŠÁK, Gracian: Pták, Bohumil [entry], in: Československý hudební slovník osob a institucí. M-Ž (Czechoslovak Musical Dictionary of Persons and Institutions. M-Ž), Státní hudební vydavatelství (State Music Publishing), Praha 1965, p. 388.

43) ŠTĚDROŇ, Bohumír: Kliment, Václav [entry], in: Československý hudební slovník osob a institucí. A-L (Czechoslovak Musical Dictionary of Persons and Institutions. A-L), Státní hudební vydavatelství (State Music Publishing), Praha 1963, p. 674. 
Dvořák's Rusalka. ${ }^{44}$ The latter aria is found on a record on the Gramophone Concert Record label released in 1908. The recording of the Arie Vodnika (Aria of the Water Goblin) with piano accompaniment lasts 2' 35". On side two, the same singer performs the song of Matouš and the other smugglers under the title Pochod podloudniku (March of the Smugglers) from Smetana's opera Hubička (The Kiss, duration: 3' 03"). ${ }^{45}$

The last of the gramophone discs we are examining $^{46}$ from the MAD collection is newer than the others. On side one is the best known aria from the opera Rusalka sung by the soprano Erma Žárská (18891971). During her brief engagement at the Metropolitan Opera in New York (for the 1915/1916 season), this opera singer made 16 recordings beginning in 1916 for the Columbia label..$^{47}$ Most of these recordings

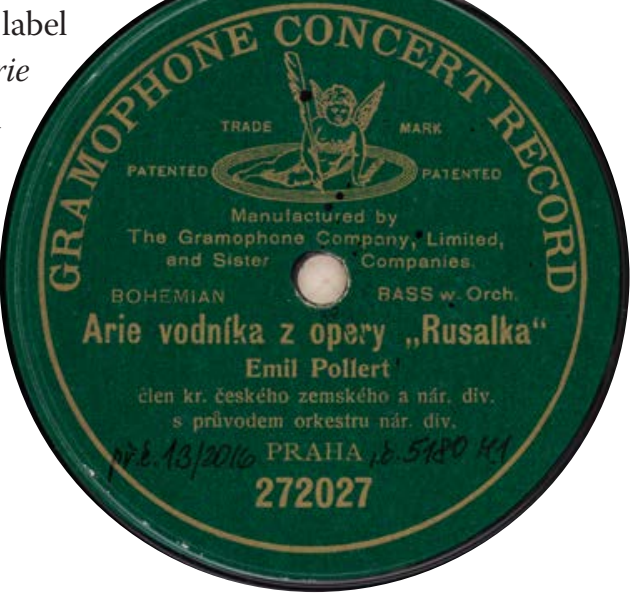

Gramophone record label of the brand Gramophone Concert Record with a recording of the aria The Whole World Will Not Give You sung by Emil Pollert, 1908 / Etiketa gramofonové desky značky Gramophone Concert Record s nahrávkou árie Celý svět nedá ti, nedá v podání Emila Pollerta, 1908 NM-ČMH-MAD $5180 \mathrm{Ml}$ are of folk songs. At least two of the recordings issued on a single gramophone disc are of the aria Měsíčku na nebi hlubokém (O Moon in the Deep Sky) from Rusalka and Vendulka's Ukolébavka (Lullaby) from Smetana's opera Hubička (The Kiss). ${ }^{48}$

\section{Conclusion}

The selection from the collection of shellac gramophone records at the Antonín Dvořák Museum used for this study contains fairly representative recordings ${ }^{49}$ of the music of Antonín Dvořák, and it documents to a limited extent but overall quite clearly the tastes of the period and the popularity of specific works. The recordings were made during the first years of development of the gramophone industry on the labels of recording companies from around the world, and the performers were leading Czech artists. Apart from a small

44) ČERNUŠÁK, Gracian: Pollert, Emil [entry], in: Československý hudební slovník osob a institucí. M-Ž (Czechoslovak Musical Dictionary of Persons and Institutions. M-Ž), Státní hudební vydavatelství (State Music Publishing), Praha 1965, pp. 340-341.

45) NM-ČMH-MAD, inv. no. 5180.

46) NM-ČMH-MAD, inv. no. 5182.

47) KŘEČEK, Vojtěch: Žárská, Hermína [entry], in: Český hudební slovník osob a institucí (Czech Musical Dictionary of Persons and Institutions). See http://www.ceskyhudebnislovnik.cz/slovnik [accessed 2 Apr. 2019].

48) SPOTTSWOOD, op. cit. in footnote no. 34 [accessed 4 Apr. 2019].

49) Not with respect to the quality of the recording, but rather as audio documentation of the vocal artistry of important Czech opera performers of the early twentieth century. 
number of recordings of instrumental compositions (e.g. Humoresque or some of the Slavonic Dances), the works by Dvořák that were most frequently recorded were songs and especially opera arias, the great majority of which are from Dvořák's most popular opera Rusalka. During the period in question, about twenty recordings of these numbers were made on the labels described in the study, ${ }^{50}$ and of those, the MAD owns about one third.

This primary research on part of the gramophone disc collection of the Antonín Dvořák Museum has attempted to offer, among other things, a basic perspective on the practice of publishing works of the classical repertoire on the first audio media, and it aims to provide information supplementing the generally known facts about the lives of Czech artists of the early twentieth century. In the future, it will also offer, for example, the possibility of comparisons with later recordings of the same works or of more in-depth research on the discography of the individual performers. Most of the selected recordings can be heard in the Kramerius digital library.

Address: Petr Kudláček, Muzeum Antonína Dvořáka, Ke Karlovu 20, 12000 Praha 2, Czech Republic

E-mail: petr_kudlacek@nm.cz

50) In view of the absence of any kind of official publications with complete lists of works published by the individual recording companies in question, one must approach this information with caution. While on the one hand, the unofficial published materials used for this study are largely complete (especially in the case of the Gramophone Concert Record label), there are considerable gaps in others, and there is a lack of dating (especially for the Pathé label). Nonetheless, all of the lists were valuable sources for basic insight into the question at hand. 


\section{Nejranější nahrávky dèl Antonína Dvořáka na}

\section{standardnich gramofonových} deskách ve fondu Muzea

\section{Antonína Dvořáka}

\section{PetrKudláček}

Studie podává stručný přehled o vybrané části hudebního fondu Muzea Antonína Dvořáka (MAD) se zaměřením na standardní (šelakové) gramofonové desky s nahrávkami děl Antonína Dvořáka, z nichž ve své druhé, hlavní části vyjímá a z historického a repertoárového hlediska analyzuje ty nejvzácnèjší, které MAD vlastní a které zároveň patří $\mathrm{k}$ nejstarším nahrávkám skladatelova díla vůbec. Celkem se jedná o deset samostatných gramofonových desek se snímky pořízenými v rozmezí let 1903-1916. Výběr je definován použitým způsobem nahrávání - původní mechanický záznam zvuku na gramofonové desky byl typický až do první poloviny dvacátých let, kdy byl postupně nahrazen modernějším elektrickým nahráváním.

Mezi nejstaršími gramodeskami obecně, stejně jako $\mathrm{v}$ př́padě zvoleného výběru $\mathrm{z}$ fondu MAD, najdeme nejčastěji nahrávky vokálních děl, což je dáno - jak bude vysvětleno později - především dobovými technickými nahrávacími možnostmi.

V našem konkrétním př́padě se jedná o některé árie z Dvořákovy nejslavnější opery Rusalka, op. 114, zkomponované roku 1900, ve dvou př́padech pak jde o nahrávky jedné písně z cyklu Cigánských melodií, op. 55, z roku 1880.

\section{Stav fondu}

Sbírka Muzea Antonína Dvořáka v současné době zahrnuje ve svém fondu hudebních nosičủ 372 inventárních čísel, pod kterými se nacházejí standardní a dlouhohrající gramofonové desky s ranými i pozdějěími nahrávkami děl Antonína Dvořáka. První zmíněné, historicky

Předkládaná práce vznikla za finanční podpory Ministerstva kultury v rámci institucionálního financování dlouhodobého koncepčního rozvoje výzkumné organizace Národní muzeum (DKRVO 2018/44, 00023272). Autor děkuje za cenné rady a poskytnuté materiály především panu Gabrielu Gösselovi a kolegům z Českého muzea hudby. 
starší a z hlediska uchování ohroženější šelakové desky čítají celkem $64^{1}$ inventárních čísel (at̉ už samostatných desek či jejich souborů - alb).

Standardní gramofonové desky získalo Muzeum Antonína Dvořáka v pěti případech darem, v dalších pěti jde o nákup od fyzických osob či z antikvariátů. V jednom případě byla převedena část nesbírkového fondu do sbírek MAD. Nejstarší akvizice byla provedena roku 1997, nejmladší pak v roce 2018.

Ve sbírce MAD jsou zastoupeny české i zahraniční gramofonové nahrávací společnosti, z nichž mnohé vznikly již na konci 19. století a zejména v první třetině 20. století působily rovněž na československém trhu s gramodeskami a gramofonovými př́ístroji. Nejvíce titulů má ve svém středu etiketu někdejší největší československé gramofonové firmy Ultraphon (21 inventárních čísel) a jejího právního nástupce, firmy Supraphon (11 inventárních čísel), která existuje dodnes. Pěti položkami je zastoupena společnost Esta (založena roku 1930), jež spolu s Ultraphonem (činným jako čistě česká firma od roku 1932)² představovala jediné dva české subjekty, zabývající se v bývalém Československu v první polovině 20. století pořizováním a vydáváním gramofonových nahrávek. Obě firmy byly v roce 1947 sloučeny a následně na základě Benešova dekretu č. 100/1945 z 24. řijna roku 1945 transformovány ve státní podnik Gramofonové závody. ${ }^{3}$

Ve fondu gramofonových desek MAD se dále nacházejí nahrávky vydané také zahraničními firmami, které v první polovině 20. století působily na československém trhu. Figurují mezi nimi vesměs všechny tehdejší světové gramofonové společnosti, jež u nás měly své pobočky nahrávající a vydávající také snímky s českým repertoárem.

Nejvíce vlastněných desek je vydáno na etiketě His Master's Voice, příp. na počeštěné verzi Hlas jeho pána (9 inventárních čísel), další snímky jsou na etiketách Columbia / Columbia Phonograph Co. (6), Gramophone Concert Record / Concert Record „Gramophone“ (4), Odeon / Odeon Record (4), Parlophon (4), Pathé (2), Telefunken (2) a Zonophone record (1).

Etiketa gramofonové desky a číselné, popřípadě písmenné údaje vyražené do hmoty gramodesky jsou př́slovečnou alfou a omegou identifikace každé nahrávky. Etiketa „v nejstručnějši verzi obsahuje pouze údaj o vydavateli či jeho logo a název snimku, v podrobnèjších verzích též údaje o interpretech a řadu dalších identifikačních znakư." Nejdůležitějším pro pomèrně přesné určení doby vzniku nahrávky je tzv. matriční číslo, které ovšem na etiketě někdy nebývá uvedeno - vždy ho však najdeme vyražené v prostoru mezi papírovou etiketou a koncem záznamu (drážky). Dalším důležitým identifikátorem, nacházejícím se na etiketě vždy, je objednací čislo, propojující gramofonovou desku, resp. snímek na ní zaznamenaný s firemním katalogem nahrávací společnosti. Obě čísla mohou mít různé prefixy či sufixy (čísla, písmena

1) Součet jednotlivých etiket rozepsaných v následujícím textu zdánlivě neodpovídá číslu 64. Důvodem je fakt, že pod inv. čślem 5093 se skrývají různé nahrávky vydané u odlišných nahrávacích společností.

2) Více k historii této české značky viz GÖSSEL, Gabriel: Fonogram 2. Výlety k počátkủm historie záznamu zvuku, Radioservis, Praha 2006, s. 505-513 (dále GÖSSEL 2006).

3) Více k průběhu znárodnění viz MÜLLER, Jan - PRAJZLER, Petr: Budování československého gramofonového průmyslu po druhé světové válce: 1945-1963, Acta phonographica, Ústí nad Labem 2017, s. 10-13.

4) GÖSSEL, Gabriel - ŠíR, Filip: Gramatika etiket gramofonových desek, Národní muzeum, Praha 2016, s. 11 (dále GÖSSEL - ŠÍR). 
či značky, předcházející, příp. následující za hlavním číslem), které přinášejí další informace, např. o průměru gramodesky, cenové kategorii, jménu nahrávacího technika apod. ${ }^{5}$

Takzvané nahrávací knihy někdejších gramofonových společností se ve většině případů nedochovaly. Datace jednotlivých nahrávek dle matričních a objednacích čísel tedy představuje zdlouhavý a náročný proces, kdy badateli projdou tisíce desek doslova rukama. S využitím dostupných propagačních a jiných materiálů jednotlivých firem a na základě srovnávání s dostupnými informacemi, týkajícími se mj. historie společností a profesního života interpretů, poté postupně dochází k určování datace jednotlivých nahrávek. ${ }^{6}$

Při kompletování údajů o vybraném gramofonovém snímku jsou největší pomůckou zmiňované firemní katalogy. Ty obsahují seznamy nahrávek (názvy skladeb) řazených vzestupně dle objednacích čísel, dále jméno autora a interpreta skladby. Některé seznamy byly sestavovány naopak - abecedně dle názvů skladeb/autorů/interpretů s dodatečně přiřazenými objednacími čísly. Katalogy jednak napomáhají při identifikaci nahrávek, jednak umožňují získání alespoň základní představy o dobové produkci dané gramofonové společnosti či nahrávaném repertoáru jednotlivých umělců.

Jak už to však u historických pramenů bývá, tak i zde čím více jdeme do minulosti, tím nacházíme méně dochovaných prodejních katalogů někdejších nahrávacích společností. Situaci komplikuje navíc několik faktů - jednotlivé řady objednacích čísel byly naplňovány na přeskáčku, ${ }^{7}$ vydávání gramofonových desek probíhalo celosvětově podle zákona nabídky a poptávky, s ohledem na trh, pro nějž byly desky určeny, a situaci nezjednodušují ani dobové časté změny majitelů, které vedly např. k reedicím starších nahrávek na nových etiketách apod. ${ }^{8}$

\section{Standardní gramofonové desky s ranými nahrávkami děl Antonína Dvořáka}

Gramofonové desky, jimiž se zabývá tato studie, získalo Muzeum Antonína Dvořáka ve třech př́padech darem od pana Josefa Lipše, ${ }^{9}$ dalších sedm nosičů pak muzeu věnoval sběratel starých gramofonových desek a popularizátor historických nahrávek pan Gabriel Gössel. ${ }^{10}$

Na osmi nahrávkách se nacházejí árie z opery Rusalka (jeden ze snímků existuje ve fondu dvakrát - podruhé v podobě reedice či takzvaném přelisu), zbývající dvě gramodesky jsou záznamy písně Když mě stará matka z cyklu Cigánské melodie, op. 55.

5) Srov. tamtéž.

6) Práce využivá dostupných soupisů gramofonových nahrávek příslušných nahrávacích společností, kteréjsou výsledkem dlouholeté badatelské činnosti významných sběratelů, jakými jsou například Gabriel Gössel (ČR), Christian Zwarg (Německo), Richard K. Spottswood (USA) a mnohých dalších sběratelů z různých zemí světa, kteři vzájemně spolupracují. Seznamy poskytují přibližná, avšak místy i velmi přesná vročení. Neocenitelnou je práce Gabriela Gössela a Filipa Šíra, kteři ve svých publikacích nabízejí návod pro dataci českých nahrávek. 7) Tzn. nikoli v chronologickém sledu a navíc často s mezerami způsobenými nenaplněním dané číselné série. 8) GÖSSEL, Gabriel - ŠÍR, Filip: Katalogy gramofonových firem ze začátku 20. století, s. 3, 7. Příspěvek byl uveřejněn na 9 . konferenci o šedé literatuře a repozitářích, konané v Národní technické knihovně v Praze 19. 10. 2016. Dostupné z http://repozitar.techlib.cz/record/1042/files/idr-1042_3.pdf [cit. 7. 3. 2019].

9) Jedná se o výběr desek z většího souboru, který Muzeum Antonína Dvořáka získalo z pozůstalosti po panu Josefu Lipšovi, jenž byl v osmdesátých letech 20. století vedoucím neoficiálního klubu sběratelů standardních gramofonových desek. NM-ČMH-MAD, př. č. 12/2005, inv. č. 8682-8684.

10) NM-ČMH-MAD, př. č. 13/2016, inv. č. 5176-5182. 


\section{Přehled nejstarších nahrávek děl Antonína Dvořáka ve sbírce MAD ${ }^{11}$}

\begin{tabular}{|l|l|l|l|l|}
\hline Rok & Název12 & Interpret & Etiketa & Inv. č. \\
\hline 1903 & Zpěv lesní žínky & M. Bobková & Zonophone record & 5176 \\
\hline 1906 & Zpěv lesní žinky & M. Bobková & Odeon Record & 5179 \\
\hline $1908-1909^{13}$ & Zpěv lesní žínky & M. Bobková & Odeon Record & 5181 \\
\hline 1905 & Cigánská píseñ & O. Mařák & Columbia Phonograph & 8684 \\
\hline 1907 & Když mě stará matka & O. Mařák & Gramophone Concert Record & 8682 \\
\hline 1907 & Zpěv prince & O. Mařák & Gramophone Concert Record & 8683 \\
\hline $1906-1908^{14}$ & Árie prince & B. Pták & Pathé Record & 5178 \\
\hline $1906-1908$ & Árie vodníka & V. Kliment & Pathé Record & 5177 \\
\hline 1908 & Árie vodníka & E. Pollert & Gramophone Concert Record & 5180 \\
\hline 1916 & Měsíčku na nebi hlubokém & E. Žárská & Columbia & 5182 \\
\hline
\end{tabular}

Uvedené tituly patří mezi nejstarší české nahrávky zaznamenané na gramofonových deskách. Vynález tohoto média spolu s gramofonovým přístrojem pro nahrávání a reprodukci zvuku si nechal roku 1887 patentovat americký vynálezce Emile Berliner. Ten v roce 1894 založil první nahrávací společnost na světě, United States Gramophone Company, a začal své desky vydávat komerčně. První české snímky spatřily světlo světa již v prvních letech 20. století. Nejvíce šlo o árie z oper Bedřicha Smetany, lidové a národní písně, ale i o pozdější československou hymnu Kde domov můj. Jejich interpretem byl český operní pěvec František Pácal, ${ }^{15}$ působící v letech 1895-1905 ve vídeňské Dvorní opeře. Zprvu byly nahrávky pořizovány ve Vídni či Berlíně, již od roku 1902 však došlo k prvnímu nahrávání také v Praze. ${ }^{16}$

Prvními interprety děl Antonína Dvořáka na nejstarších gramofonových deskách byli operní pěvci, kteří tytéž role ztvárňovali na jevišti pražského Národního divadla. Některá z těchto jmen se vyskytují na předloženém soupisu nahrávek sbírky MAD. Mezi tehdejšími osobnostmi tak najdeme například Růženu Maturovou, Václava Klimenta, Otakara Mařáka, Málku Bobkovou, Emila Pollerta, Marii Klánovou, Annu Slavíkovou, Bohumila Ptáka, již zmiňovaného Františka Pácala a další. Kromě árií z oper českých a světových skladatelů tito pěvci interpretovali rovněž národní písně a úpravy písní lidových. Z děl Antonína Dvořáka se jedná ve velké míře o árie z opery Rusalka a skladatelovu písňovou tvorbu.

Nejstarší gramofonová nahrávka ve sbírce MAD ${ }^{17}$ pochází z roku 1903 a na její první straně je zaznamenána árie lesní žínky Mám zlaté vlásky, mám z 3. dějství opery Rusalka v podání

11) Uvedený seznam je řazen chronologicky. Pro zachování co největší přehlednosti je také prihlédnuto k řazení jednotlivých nahrávek dle jména interpreta, př́p. názvu nahrané skladby.

12) Názvy jsou ponechány v podobě, v jaké jsou uvedeny na etiketách gramodesek.

13) Jedná se o přelis (reedici) nahrávky z roku 1906.

14) Datace v prípadě nahrávací společnosti Pathé je velmi sporadická a obtí̌ná.

15) Na raných gramofonových etiketách uváděn jako Franz Pacal.

16) GÖSSEL, Gabriel: Gramophone Company Czech Catalogue 1900-1915.doc-elektronickýzdroj jev soukromém majetku p. Gössela [cit. 9. 3. 2019] (dále GÖSSEL: Catalogue).

17) NM-ČMH-MAD, inv. č. 5176. 
Málky Bobkové s klavírním doprovodem. ${ }^{18}$ Na druhé straně desky najdeme českou lidovou píseň Ach, není tu, není, kterou (rovněž s průvodem klavíru) nazpívala jistá Josefina Krausová. Nahrávka byla pořízena již počátkem roku 1902 v Berlíně. Text této písně zhudebnil Antonín Dvořák roku $1886^{19} \mathrm{~s}$ využitím některých prvků původních lidových nápěvů. Na zmiňované nahrávce se však jedná o původní lidovou verzi písně.

Dobové technické možnosti umožňovaly zaznamenávání jen omezeného repertoáru a pořizování nahrávek v délce pouze několika málo minut. Tzv. mechanické nahrávání, charakteristické pro první etapu vývoje záznamu zvuku, bylo limitováno zejména nízkou citlivostí tehdejších zvukových membrán, schopných nejlépe zaznamenat jen střední tónové frekvence. Samotný proces nahrávání navíc spočíval v co nejtěsnějším přistoupení interpreta k nahrávacímu trychtýři. Tak bylo možné nahrávat s uspokojivým výsledkem pouze lidský hlas či houslová sóla. Z kapacitních důvodů tehdejších gramofonových kotoučů pak byly zaznamenávány jen krátké skladby, které byly navíc různě zkracovány či upravovány (což je i př́ípad některých nahrávek ve fondu MAD) ${ }^{20}$ Árie lesní žínky dosahuje časové délky jedna minuta a čtyřicet vteřin. Druhá strana má délku celé dvě minuty.

Nahrávka vyšla na jedné $\mathrm{z}$ nejstarších světových gramofonových etiket $\mathrm{s}$ názvem Zonophone Record. Tato značka patřila původně americké nahrávací společnosti The International Zonophone Company, založené roku 1899 Frankem Seamanem ve státě New Jersey. Pro svůj počáteční úspěch, který firma zaznamenala se snímky světových operních pěvců (včetně Enrica Carusa), tato společnost brzy představovala nežádoucí konkurenci pro tehdejší největší nahrávací společnosti - jedna z nich, anglická společnost The Gramophone Company Ltd., značku koncem roku 1903 koupila a začala ji užívat jako svoji vedlejší a lacinější etiketu vyhrazenou pro umělecky méně náročný, převážně lidový repertoár, s výjimkou několika málo nahrávek koncertních souborů a operních pěvců (Emil Pollert, Otakar Mařák, Bohumil Benoni, Václav Kliment, Mirko Štork). Nahrávky určené pro země tehdejšího Rakouska-Uherska byly vydávány na deskách o průměru 7" a 10", měly temně zelenou etiketu s nápisem „Zonophone Record“ a vycházely v řadě katalogových objednacích čísel 100.000. ${ }^{21}$ Nahrávka s árií lesní žínky nese číselné označení 103027, druhá strana 103028, deska má průměr necelých $18 \mathrm{~cm}$, tedy zhruba 7 palců.

Málka (Amálie) Bobková (1874-1956) byla jednou z nejvýznamnějších operních pěvkyň počátku 20. století. V roce 1901 získala po několika pohostinských vystoupeních stálé angažmá v pražském Národním divadle, v němž setrvala deset let a kde s úspěchem interpretovala dívčí postavy v operních dílech českých i zahraničních skladatelů (Bedřicha Smetany,

18) Jedná se zároveň o nejstarší nahrávku této árie vůbec. Srov. ŠÍR, Filip - GÖSSEL, Gabriel: Unikátní nahrávky árii z Dvořákovy Rusalky na šelakových gramodeskách z počátku 20. století. Dostupné z http://muzeum3000. nm.cz/clanek/unikatni-nahravky-arii-z-dvorakovy-rusalky-na-selakovych-gramodeskach-z-pocatku-20stoleti [cit. 9. 3. 2019]. Článkem zmiňovaný rok 1902 odkazuje na nejstarší zaznamenanou árii z Rusalky celkově (jde o árii prince v podání Stanislava Orzelského), konkrétně zpěv lesní žínky byl však pořízen v roce 1903 v Praze. Viz GÖSSEL: Catalogue, elektronický zdroj cit. v pozn. 16.

19) Spolu s dalšími třemi zhudebněnými texty slovenských písníji vydal v rámci cyklu $V$ národním tónu, op. 73.

20) Srov. LOCHMAN, Adolf: Gramofonová deska, Práce, Praha 1955, s. 36-37.

21) GÖSSEL 2006, op. cit. v pozn. 2, s. 530-533. 
Antonína Dvořáka, Wolfganga Amadea Mozarta a dalších). Z Dvořákových děl ztvárnila Málka Bobková na jevišti Národního divadla za svoji kariéru v nejvíce př́ípadech právě lesní žínku (alternovala též v roli Kuchtíka). ${ }^{22}$ Tuto roli zpívala také při premiéře Rusalky dne 31. března roku 1901 v Národním divadle v Praze. Jak v tomto Dvořákově díle, tak i v jiných, kde účinkovala (Šelma sedlák, Armida, Requiem, Dimitrij, Jakobin), vystupovala po boku mnohých význačných pěveckých kolegů, $\mathrm{s}$ nimiž v době rychlého nástupu gramofonových desek nahrávala (samostatně či v duetech) první snímky (Anna Slavíková, Marie Klánová, Otakar Mařák, František Pácal, Bohumil Pták, Václav Kliment, Emil Pollert a Bohumil Benoni). Zvlášt s Otakarem Mařákem utvořila sehranou dvojici. Oporou repertoáru Málky Bobkové v Národním divadle byly opery Bedřicha Smetany. ${ }^{23}$ Stejně tak $\mathrm{v}$ př́padě nahrávek pořizených pro nahrávací společnost The Gramophone Company E. Berlinera jde nejčastěji o Smetanova díla (největší počet nastudování má na svém kontě role Vendulky

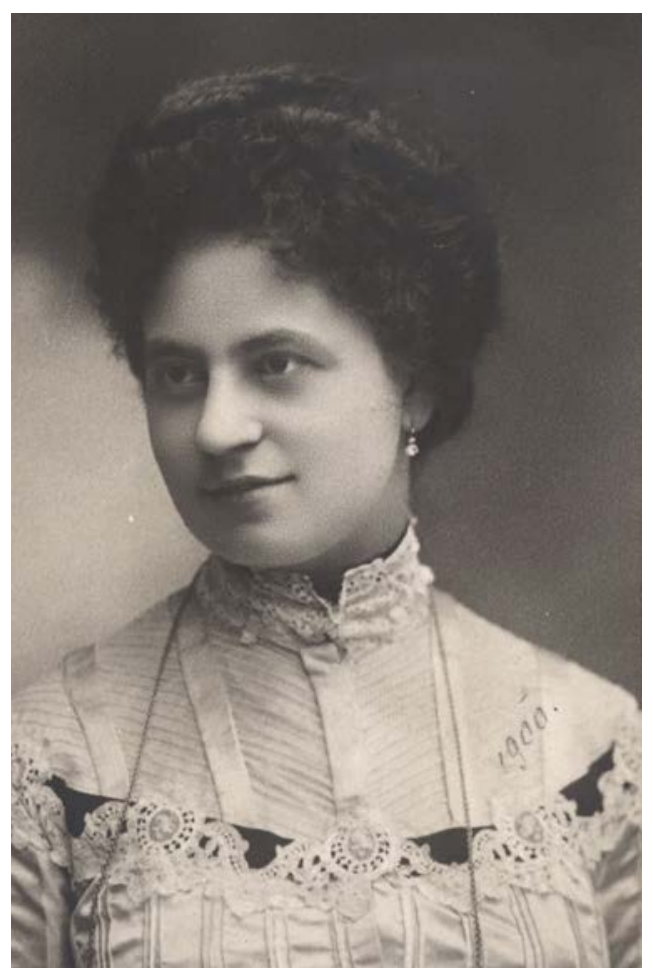

Amálie Bobková (1874-1956)

Photograph, unknown photographer, Prague, ca. 1900 / Fotografie, autor neznámý, Praha, kol. 1900

NM-HM, Department of Theatre / Divadelní oddělení H6D-8F96 z opery Hubička). Málka Bobková pro zmiňovanou společnost pořídila celkem 27 nahrávek v letech 1902-1908, přičemž nejvíce snímků natočila v roce 1905 (celkem šest). ${ }^{24}$

Podobně jako jiní interpreti i Málka Bobková časem uplatnila árie, které zpívala na divadelních jevištích, u více gramofonových společností. Další známou značkou, na jejíž desky natáčelo mnoho českých umělců, byla etiketa Odeon. Tu roku 1903 založila v Berlíně firma International Talking Machine, která již následujícího roku přišla na trh s oboustranně nahranou gramofonovou deskou. Jelikož v té době byl standardem jednostranný záznam, zajistil tento počin firmě velký úspěch a tím rychlou expanzi do Evropy a USA. ${ }^{25}$ Jako v případě firmy E. Berlinera, také u Odeonu byly české snímky natáčeny zpočátku v Berlíně či

22) Srov. Národní divadlo. Soupis repertoáru od roku 1883. Dostupné z http://archiv.narodni-divadlo.cz [cit. 9. 3. 2019].

23) ŠTĚDROŇ, Bohumír: Bobková, Amálie [heslo], in: Československý hudební slovník osob a institucí. A-L, Státní hudební vydavatelství, Praha 1963, s. 112. Srov. cit. Soupis repertoáru od roku 1883, viz pozn. 22.

24) GÖSSEL: Catalogue, elektronický zdroj cit. v pozn. 16.

25) GÖSSEL 2006, op. cit. v pozn. 2, s. 452. 
ve Vídni, záhy se však produkce přesunula do Prahy. Prvenství v pořízení nahrávek připadá opět Františku Pácalovi a také Vilému Hešovi, kteří stojí za dvěma desítkami snímků. První operní nahrávky natočené pro Odeon v Praze pocházejí z let 1906-1907 a objevují se na nich i další známá jména, včetně některých interpretů zachycených na deskách MAD: Otakar Mařák, Málka Bobková, Bohumil Pták, Václav Kliment, Emil Burian, Anna Slavíková a další. Jedním z nejagilnějších byl (podobně jako u jiných značek, pro které nahrával) Otakar Mařák (přes třicet snímků), téměř dvojnásobným počtem ho však předčil Emil Burian. ${ }^{26}$

Repertoár nahrávaný pro značku Odeon se v zásadě nelišil od konkurence - převažují skladby Bedřicha Smetany, lidové a národní písně, z děl Antonína Dvořáka jsou opět nejčastějšími árie z Rusalky, skladatelova písňová tvorba a některé Slovanské tance.

Málka Bobková natočila mezi lety 1906-1908 pro značku Odeon celkem 17 gramofonových snímků (z toho 11 sólově), na nichž je nejvíce zastoupeno dílo Bedřicha Smetany. ${ }^{27}$ Pravděpodobně jediná nahrávka díla Antonína Dvořáka, kterou tato umělkyně pro tuto značku pořídila, se shoduje s první stranou gramofonové desky ve sbírce MAD, ${ }^{28}$ vydané roku 1906. Opět jde o árii lesní žínky s doprovodem klavíru (délka nahrávky je 2:11), přičemž na druhé straně najdeme Romanci z opery Mignon od francouzského operního skladatele Ambroise Thomase (v délce 3:26). Tatáž nahrávka ${ }^{29}$ se ve sbírce nalézá ještě ve formě přelisu, tedy reedice, s přibližnou datací 1908-1909. ${ }^{30}$

Druhou nejstarší gramofonovou nahrávkou $\mathrm{s}$ dílem Antonína Dvořáka z fondu MAD je Cigánská píseñ, kterou roku 1905 nazpíval s doprovodem klavíru již několikrát zmiňovaný Otakar Mařák. ${ }^{31}$ Pod tímto názvem uvedeným na etiketě firmy Columbia Phonograph Co. se skrývá čtvrtá píseň z cyklu sedmi Cigánských melodii, op. 55, Když mě stará matka. Jedná se o jednostrannou desku $\mathrm{s}$ délkou záznamu dvě minuty a padesát devět vteřin. ${ }^{32}$

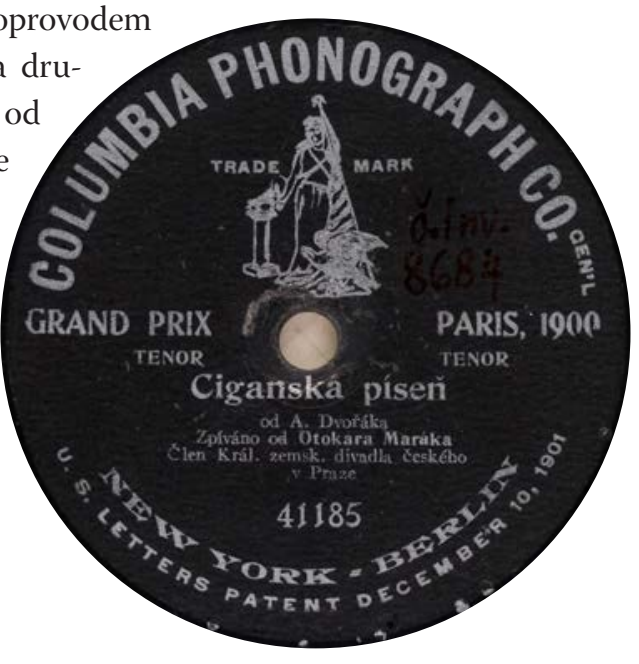

Gramophone record label of the brand Columbia Phonograph Co. with a recording of the song Songs My Mother Taught Me sung by Otakar Mařák, 1905 / Etiketa gramofonové desky značky Columbia Phonograph Co. s nahrávkou písně Když mě stará matka v podání Otakara Mařáka, 1905 NM-ČMH-MAD $8684 \mathrm{Ml}$

26) GÖSSEL, Gabriel: LINDSTRÖM_A_DISKO.xls elektronický zdroj je v soukromém majetku p. Gössela [cit. 10. 3. 2019].

27) Op. cit. v pozn. 26 [cit. 10. 3. 2019].

28) NM-ČMH-MAD, inv. č. 5179.

29) NM-ČMH-MAD, inv. č. 5181.

30) ZWARG, Christian: Odeon.xls - elektronický zdroj, dostupný z https://www.truesoundtransfers.de/disco. htm [cit. 10. 3. 2019].

31) Na etiketách prvních gramodesek byl uváděn jako Otokar Mařák.

32) NM-ČMH-MAD, inv. č. 8684. 
Počátky historie společnosti Columbia Phonograph Co. sahají do Spojených států amerických na přelomu 80. a 90. let 19. století. Firma původně vydávající fonografické válečky rozšírila nabízené zboží o vlastní nahrávané gramofonové desky roku 1901 a o rok později měla již regionální zastoupení také pro české země. ${ }^{33}$ Stejně jako v př́padě konkurenčních společností, také Columbia se orientovala na uspokojení vkusu posluchačů a zaměřovala se na vydávání populární hudby, komických výstupů i oblíbených árií oper českých a zahraničních skladatelů. Opět se tak setkáváme s lidovými a národními písněmi a také áriemi v podání předních operních pěvců, jako byli např. Otakar Mařák (téměř čtyři desítky snímků), Václav Kliment, Emil Pollert, František Šír aj., v pozdějších letech se objevují také Bohumil Pták či Erma Žárská. Repertoár této nahrávací firmy ovšem dle dostupných údajư ${ }^{34}$ nebyl pro české země tak obsáhlý jako u předešlých dvou zmíněných společností. Nejčetněji jsou zde zastoupeny Smetanovy opery a opera Vstudni Viléma Blodka. Dvořákovo dílo je reprezentováno jedním snímkem - výše zmiňovanou deskou, vlastněnou MAD.

Tutéž skladbu jako na značce Columbia, tentokrát pod konkrétním názvem Když mě stará matka, nahrál Otakar Mařák také o dva roky později na oboustrannou gramofonovou desku s etiketou Gramophone Concert Record firmy The Gramophone Company. Jedná se opět o zpěv $\mathrm{s}$ klavírem v délce dvě minuty a padesát vteřin. Druhá strana desky obsahuje píseň $O$, jak jsi krásná z pera Emanuela Chvály (2:42), interpretovanou rovněž Otakarem Mařákem. ${ }^{35}$

Tento operní pěvec, jehož nejslavnější období spjaté s pražským Národním divadlem spadá do let 1903-1907, se pro své dokonalé ovládnutí domácího i světového repertoáru stal nejoblíbenějším a nejobsazovanějším členem operního souboru tohoto divadla. Byl nejpřednějším interpretem všech Smetanových oper, vynikal i v dílech Antonína Dvořáka a dalších českých klasiků. ${ }^{36}$ Jako všestranný pěvec s operním, ale také koncertním repertoárem se velmi angažoval v rozvíjejícím se gramofonovém průmyslu, o čemž svědčí hojnost záznamů v řadě seznamů nahrávek gramofonových společností, s nimiž tato studie pracuje.

Otakar Mařák pořídil pro The Gramophone Company na sklonku roku 1907 v rámci jedné nahrávací frekvence celkem 10 snímků. Vedle zmiňované písně Když mě stará matka najdeme ve sbírce MAD také desku se záznamem árie prince Vidino divná, přesladká, uvedenou na etiketě pod obecným názvem Zpěv prince. Jedná se o zpěv s blíže nespecifikovaným orchestrálním doprovodem v délce dvě minuty a čtyřicet pět vteřin. Na druhé straně je Árie Jarka ze Smetanovy opery Čertova stěna (2:57). ${ }^{37}$

33) GÖSSEL 2006, op. cit. v pozn. 2, s. 367-368.

34) GÖSSEL, Gabriel: COLUMBIA_cz_stará.doc - elektronický zdroj je v soukromém majetku p. Gössela [cit. 12. 3. 2019]; SPOTTSWOOD, Richard: The Columbia Series, 2016 - elektronický zdroj, dostupný z https://78records.files.wordpress.com/2016/08/columbia-e_spottswood.pdf [cit. 16. 3. 2019] (dále SPOTTSWOOD).

35) NM-ČMH-MAD, inv. č. 8682.

36) ŠTĚDROŇ, Bohumír: Mařák, Otakar [heslo], in: Československý hudební slovník osob a institucí. M-Ž, Státní hudební vydavatelství, Praha 1965, s. 56-57.

37) NM-ČMH-MAD, inv. č. 8683. 
Další dvojice gramofonových desek byla vydána u francouzské společnosti Pathé mezi lety 1906 a 1908. První titul ${ }^{38}$ má na své etiketě opět obecnější název Árie prince, pod nímž se tentokrát skrývá árie Vim, že jsi kouzlo v podání Bohumila Ptáka. Zpěv s doprovodem orchestru neznámého složení trvá dvě minuty a dvacet devět vteřin. V interpretaci téhož operního pěvce je na druhé straně desky zaznamenána Árie Ctirada z opery Šárka skladatele Zdeňka Fibicha (2:34).

Druhá deska ${ }^{39}$ přináší záznam árie Celý

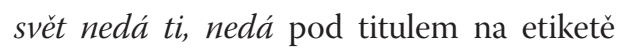
Árie vodníka (délka 2:36), na druhé straně se nachází Árie Beneše z opery Dalibor (2:35). Na obou stranách je interpretem vokálního partu Václav Kliment.

Gramofonová firma Pathé, jejíž etiketa existuje ve Francii dodnes, vznikla roku

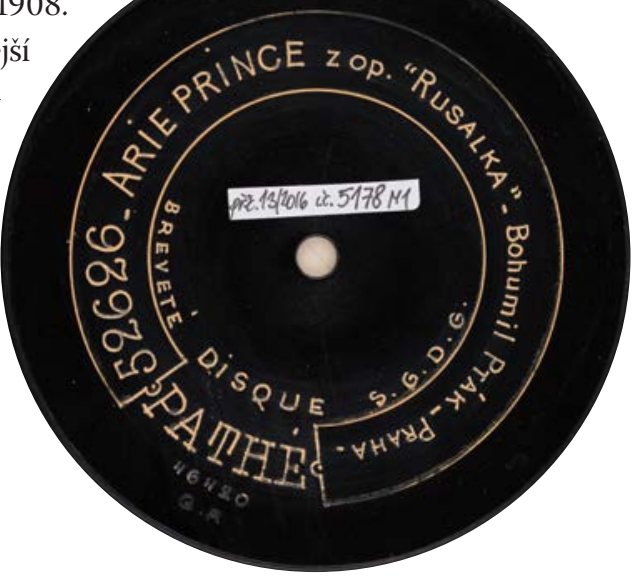

Gramophone record label of the brand Pathé with a recording of the aria I Know You Are Magic sung by Bohumil Pták, 1906-1908 / Etiketa gramofonové desky značky Pathé s nahrávkou árie Vím, že jsi kouzlo v podání Bohumila Ptáka, 1906-1908 NM-ČMH-MAD $5178 \mathrm{Ml}$ 1895 v Paříži jako firma na výrobu fonografických válečků, která zakrátko přistoupila i k samotnému pořizování záznamů a později přidala také výrobu vlastních fonografů. Společnost zažívala velké úspěchy, o čemž svědčí fakt, že pravidelnou výrobu gramodesek zavedla až roku 1906, tedy v době, kdy již bylo jasné, které záznamové médium ovládne v budoucnu gramofonový trh. Produkty firmy Pathé se vyznačovaly několika technickými specifiky. Desky s touto značkou měly neobvyklé parametry jako rychlost otáčení 90-100ot./min. (oproti ustálené rychlosti 78 ot./min), zvukový záznam (tedy drážka) směřoval od prostředku desky k jejímu okraji a byl pořizován tzv. hloubkově, což byl způsob typický pro voskové válečky, lišící se od stranového záznamu používaného u gramofonových desek. Tyto desky měly také neobvyklé průměry a zpočátku byly jednostranné a postrádaly tradiční papírovou etiketu. Pro jejich přehrávání byl potřeba speciální gramofon. ${ }^{40}$

Střed popisovaných gramodesek ze sbírky MAD je charakteristický právě absencí papírové etikety - údaje o nahrávce jsou vyryty přímo do hmoty desky a zvýrazněny bílým plnidlem. Rovněž průměr 29 cm (11,5") odpovídá zmiňovaným atypickým rozměrům. Český repertoár se na gramofonových deskách firmy Pathé začal objevovat od roku 1906 a pořízeno bylo pro tuto společnost zhruba 850 nahrávek. Datace prvních desek bez papírových etiket odpovídá rozmezí let 1906-1908. ${ }^{41}$ Z operních pěvců natočili své snímky například Marie Kubátová, Olga Valoušková, Václav Kliment, Bohumil Pták, František Šír a jiní. Árii z opery

38) NM-ČMH-MAD, inv. č. 5178.

39) NM-ČMH-MAD, inv. č. 5177.

40) GÖSSEL 2006, op. cit. v pozn. 2, s. 480-481.

41) GÖSSEL - ŠÍR, op. cit. v pozn. 4, s. 59. 
Rusalka (Píseň prince) natočil pro zmiňovanou společnost také Stanislav Orzelski.

Bohumil Pták (1869-1933), operní pěvec s poměrně širokým repertoárem, byl $\mathrm{v}$ angažmá v pražském Národním divadle v letech $1896-$ 1911 a osvědčil se jako interpret hrdinných a lyrických postav zvlášt v smetanovském repertoáru. ${ }^{42}$ Byl prvním interpretem řady postav z českých oper, včetně postavy Prince v Dvořákově Rusalce, v níž na poslední chvíli nahradil Karla Buriana, který však zůstal uveden na divadelní ceduli k premiére.

Václav Kliment (1863-1918), který rovněž patřil $\mathrm{k}$ předním pěvcům české první scény (angažován byl v roce 1893 a setrval zde až do konce svého života), se také zúčastnil uvedení řady českých operních novinek, při premiére Rusalky ztvárnil Vodníka. ${ }^{43}$

Premiéry Dvořákovy nejslavnější opery se týká také následující gramofonová na-

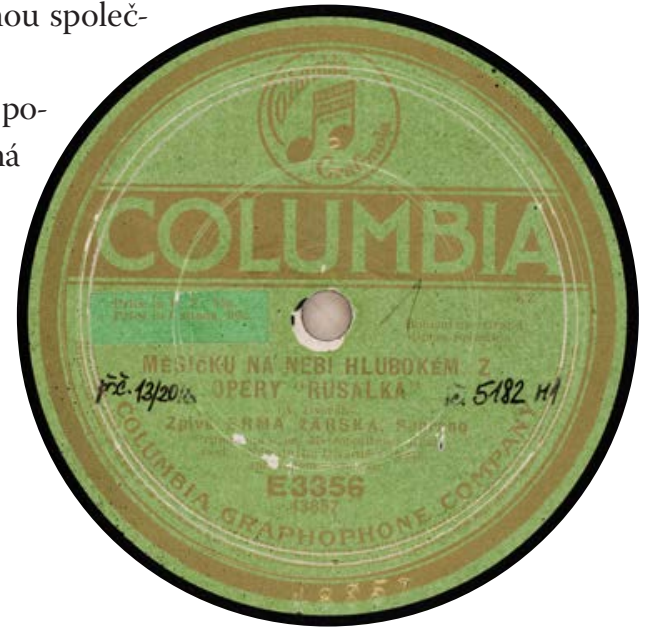

Gramophone record label of the

brand Columbia with a recording of the aria Song to the Moon sung by Erma Žárská, 1916 / Etiketa gramofonové desky značky Columbia s nahrávkou árie Měsičku na nebi hlubokém v podání Ermy (Hermíny) Žárské, 1916

NM-ČMH-MAD $5182 \mathrm{Ml}$ hrávka, nacházející se ve sbírce MAD. Emil Pollert (1877-1935), jeden z nejvýraznějších a nejúspěšnějších představitelů basových komických rolí, vynikl především jako Kecal ve Smetanově Prodané nevěstě či jako Vodník v Dvořákově Rusalce. ${ }^{44}$ Právě nahrávka druhé ze zmiňovaných árí se nachází na desce s etiketou Gramophone Concert Record a vydána byla roku 1908. Záznam Árie Vodníka s doprovodem klavíru trvá dvě minuty a třicet pět vteřin (v podání téhož pěvce zní z druhé strany desky zpěv Matouše a dalších pašírư pod názvem Pochod podloudníků ze Smetanovy Hubičky, doba trvání 3:03).45

Poslední z popisovaných gramodesek ${ }^{46}$ ze sbírek MAD je oproti předešlým mladšího data a obsahuje na své jedné straně nejznáměǰ̌i árii z opery Rusalka v podání sopranistky Ermy Žárské (1889-1971). Tato operní pěvkyně pořídila během svého krátkého angažmá u newyorské Metropolitní opery (v sezóně 1915/1916) počátkem roku 1916 pod značkou Columbia celkem 16 snímkủ, ${ }^{47} \mathrm{z}$ nichž většinu tvoř́ lidové písně. Nejméně dvě nahrávky, vydané na

42) ČERNUŠÁK, Gracian: Pták, Bohumil [heslo], in: Československý hudební slovník osob a institucí. M-Ž, Státní hudební vydavatelství, Praha 1965, s. 388.

43) ŠTĚDROŇ, Bohumír: Kliment, Václav [heslo], in: Československý hudební slovník osob a institucí. A-L, Státní hudební vydavatelství, Praha 1963, s. 674.

44) ČERNUŠÁK, Gracian: Pollert, Emil [heslo], in: Československý hudební slovník osob a institucí. M-Ž, Státní hudební vydavatelství, Praha 1965, s. 340-341.

45) NM-ČMH-MAD, inv. č. 5180.

46) NM-ČMH-MAD, inv. č. 5182.

47) KŘEČEK, Vojtěch: Žárská, Hermína [heslo], in: Český hudební slovník osob a institucí. Dostupné z http:// www.ceskyhudebnislovnik.cz/slovnik [cit. 2. 4. 2019]. 
jedné gramodesce, jsou záznamy árie Měsíčku na nebi hlubokém a Ukolébavky Vendulky ze Smetanovy Hubičky. ${ }^{48}$

\section{Závěr}

Použitý výběr ze sbírky gramofonových šelakových desek Muzea Antonína Dvořáka obsahuje poměrně reprezentativní nahráv$\mathrm{ky}^{49} \mathrm{~s}$ dílem Antonína Dvořáka a v omezené míre, avšak vcelku jasně dokumentuje dobový vkus a oblibu konkrétních děl. Nahrávky byly pořízeny v prvních letech rozvíjejícího se gramofonového průmyslu na značkách světových nahrávacích společností a interpretovány předními českými umělci. Kromě několika málo snímků instrumentálních skladeb (např. Humoreska či některé Slovanské tance) byly nejčastěji nahrávány Dvořákovy písně a zejména árie, které v naprosté většině pocházejí z Dvořákovy nejoblíbenější opery Rusalka. Ve sledovaném období jich byly na popisovaných značkách

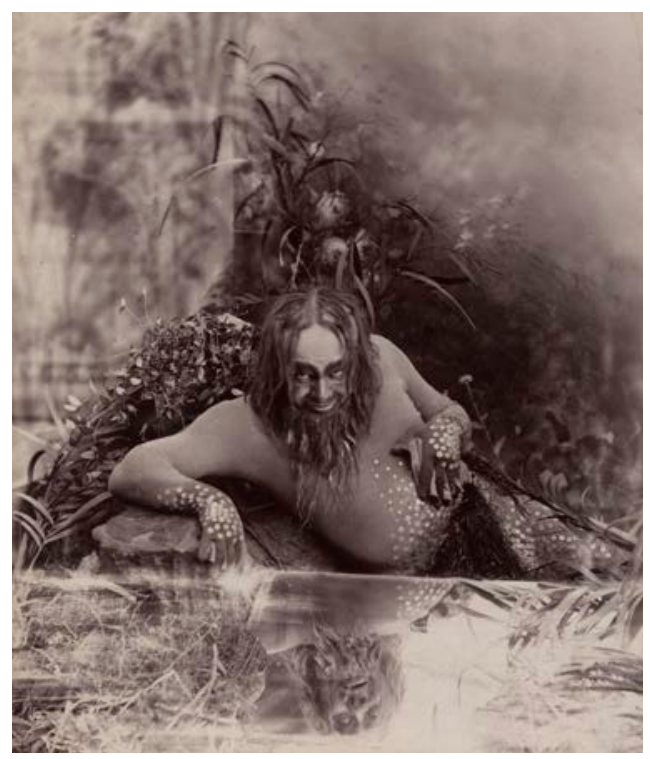

Václav Kliment (1962-1918) in the role of the Water Goblin / v roli Vodníka

Photograph, K. Maloch, Prague, early $20^{\text {th }}$ century / Fotografie, K. Maloch, Praha, poč. 20. století NM-HM, Department of Theatre / Divadelní oddělení H6D-12F3 nahrány zhruba dvě desítky, ${ }^{50} \mathrm{z}$ nichž v majetku MAD je asi jedna třetina.

Tento primární výzkum části fondu gramofonových desek Muzea Antonína Dvořáka se pokusil nabídnout mimo jiné základní vhled do praxe vydávání děl klasického repertoáru na prvních zvukových nosičích a doplnit informace k obecně známým faktům ze života českých umělců počátku 20. století. V budoucnu poskytuje např. možnost srovnání s pozdějšími nahrávkami týchž děl či hlubší bádání na poli diskografie jednotlivých interpretů. Většinu vybraných nahrávek je možné si poslechnout v digitální knihovně Kramerius.

\section{Adresa: Petr Kudláček, Muzeum Antonína Dvořáka, Ke Karlovu 20, 12000 Praha 2, Česká republika} E-mail: petr_kudlacek@nm.cz

48) SPOTTSWOOD, op. cit. v pozn. 34 [cit. 4. 4. 2019].

49) Nikoli z pohledu kvality záznamu, nýbrž jako zvukový doklad pěveckého umění významných českých operních interpretů počátku 20. století.

50) Vzhledem k absenci jakýchkoli oficiálních publikací s kompletními seznamy vydaných děl jednotlivých sledovaných nahrávacích společnostíje potřeba k uváděným údajům přistupovat s rezervou. Zatím neoficiálně vydané materiály, s nimiž tato studie pracovala, jsou na jedné straně z velké části kompletní (zejména $\checkmark$ př́padě značky Gramophone Concert Record), jiné však vykazují značné mezery a absenci datace (převážně u firmy Pathé). Přesto byly všechny seznamy cenným zdrojem pro základní vhled do dané problematiky. 